\title{
Comparison of flag leaf and ear photosynthesis with biomass and grain yield of durum wheat under various water conditions and genotypes
}

\author{
Hanane ABBAD ${ }^{\mathrm{a}}$, Samir El JAAFARI ${ }^{\mathrm{b}}$, Jordi BORT ${ }^{\mathrm{c}}$, Jose Luis ARAUS ${ }^{\mathrm{c} *}$

 \\ ${ }^{\mathrm{b}}$ Laboratoire de Biotechnologie et Amélioration des Plantes, Faculté des Sciences, Université Moulay Ismail, BP 4010, 50000 Meknes, Morocco \\ ${ }^{\mathrm{c}}$ Unitat de Fisiologia Vegetal, Facultat de Biologia, Universitat de Barcelona, Diagonal 645, 08028 Barcelona, Spain
}

(Received 21 May 2003; accepted 17 November 2003)

\begin{abstract}
Photosynthetic activity of cereals has traditionally been studied using leaves, thus neglecting the role of other organs such as ears. Here, we studied the effects of water status and genotypes on the photosynthetic activity of the flag leaf blade and the ear of durum wheat. The various parameters related to the photosynthetic activity were analysed in relation to the total above-ground plant biomass and grain yield at maturity. Four local varieties plus two cultivars adapted to the semiarid areas of South Morocco were grown in pots in a greenhouse. Five different water treatments were maintained from the beginning of stem elongation to maturity, when shoot biomass and grain yield were recorded. The net photosynthesis $(A)$, stomatal conductance $\left(g_{s}\right)$ and transpiration $(T)$ of the ear and the flag leaf were measured at anthesis. In both organs these factors decreased significantly with water deficit, whereas the $\mathrm{A} / \mathrm{T}$ and $\mathrm{A} / \mathrm{g}_{\mathrm{s}}$ ratios increased. The genotype effect was also significant for all traits studied. Whole-organ photosynthesis was much higher in the ear than in the flag leaf in well-watered conditions. As water stress developed, photosynthesis decreased less in the ear than in the flag leaf. Whole-ear photosynthesis correlated better than flag leaf photosynthesis with biomass and yield. Nevertheless, the relationships of the whole flag leaf with biomass and yield improved as the water stress became more severe, suggesting a progressive shift of yield from sink to source limitation. For all water regimes the ratios A/g and A/T of the ear also showed a higher (negative) correlation with both biomass and yield than those of the flag leaf. The results indicate that the ear has a greater photosynthetic role than the flag leaf in determining grain yield, not only in drought but also in the absence of stress.
\end{abstract}

durum wheat / ear / flag leaf / photosynthesis / yield / drought

Résumé - Comparaison des relations entre photosynthèse de la feuille étendard et de l'épi avec la biomasse et le rendement en grain chez le blé dur sous différents régimes hydriques. Traditionnellement, lorsque l'activité de la photosynthèse de céréales est étudiée, l'importance est attribuée aux feuilles, négligeant ainsi le rôle d'autres organes comme l'épi. Ici, une étude comparative de l'effet du statut hydrique sur l'activité photosynthétique au niveau de la feuille étendard et de l'épi ainsi que leurs relations avec la biomasse totale aérienne et le rendement en grain à maturité a été menée chez le blé dur. Quatre variétés locales et 2 cultivars adaptés aux zones semi-arides du sud du Maroc ont été mis en croissance dans des pots en conditions de serre. Cinq différents régimes hydriques ont été instaurés du début de l'élongation des tiges jusqu'à maturité. La biomasse et le rendement en grain sont alors enregistrés. Des mesures de la photosynthèse nette (A), de la conductance stomatique $\left(\mathrm{g}_{\mathrm{s}}\right)$ et de la transpiration $(\mathrm{T})$ ont été effectuées au niveau de l'épi et de la feuille à l'anthèse. Pour les deux organes, on note une diminution de tous ces paramètres en condition de stress hydrique, alors que les rapports $\mathrm{A} / \mathrm{T}$ et $\mathrm{A} / \mathrm{g}_{\mathrm{s}}$ augmentent. L'effet du génotype a été significatif pour tous les caractères étudiés. En conditions irriguées, la photosynthèse de l'épi est beaucoup plus élevée que celle de la feuille. Au fur et à mesure que le stress hydrique se développe, la photosynthèse de l'épi diminue moins que celle de la feuille étendard. Indépendamment du niveau du stress appliqué, on note une meilleure corrélation de la photosynthèse de l'épi avec la biomasse et le rendement par rapport à celle notée avec la feuille étendard. Néanmoins, à mesure que le stress hydrique s'accentue, cette corrélation avec la feuille étendard s'améliore, suggérant un changement progressif de la limitation du rendement des organes « puit » aux organes « source ». Au niveau de l'épi, les rapports $\mathrm{A} / \mathrm{T}$ et $\mathrm{A} / \mathrm{g}_{\mathrm{s}}$ montrent aussi une meilleure corrélation que celles de la feuille étendard à la fois avec la biomasse et le rendement ; pour la plupart des régimes hydriques, la corrélation est négative. Ces résultats suggèrent l'importance du rôle photosynthétique de l'épi dans l'élaboration du rendement par rapport à celui de la feuille étendard, non seulement en conditions de sécheresse mais aussi son absence de stress.

blé dur / épi / feuille étendard / photosynthèse / rendement / sécheresse

List of abbreviations: A, net photosynthesis rate; ASW, available water in the pot substrate; $\mathrm{g}_{\mathrm{s}}$, stomatal conductance; GYP, grain yield per plant; T, transpiration rate; RWC, relative water content; SBP, total shoot biomass per plant at maturity; TE, transpiration efficiency, the ratio $\mathrm{A} / \mathrm{T}$.

$\dagger$ Deceased.

* Corresponding author: josel@ porthos.bio.ub.es 


\section{INTRODUCTION}

Durum wheat is the most widely cultivated cereal across the Mediterranean basin, mainly under rain-fed conditions, with drought stress usually occurring during the period of grain filling $[3,18]$. Although the flag leaf has traditionally been considered the main photosynthetic organ for grain filling [12], the ear also contributes. However, reports on the photosynthetic contribution of the ear to final grain weight vary widely, depending not only on species and genotypes, but also on growing conditions. Thus, for bread wheat and barley, reports on the contribution of the ear range between $10 \%$ and $76 \%$ of yield $[4,9]$.

Besides its longer duration as a photosynthetic organ or its shorter distance from the sink (i.e. the growing grains) [11], there are other factors favouring the role of the ear over the flag leaf. The relative size of the two photosynthetic organs may also be involved [5]. For durum wheat the awned nature of the ear substantially increases the photosynthetic area of this organ and thus its whole photosynthesis [5] while it shades the flag leaf. Differences in transpiration efficiency (TE, the ratio of net photosynthesis to transpiration) between the ear and the leaves may also be involved in the greater photosynthetic role of the ear during grain filling. Even though the ear is usually the warmest organ of the plant (Araus et al., unpublished results), in our studies, in well-watered conditions, the TE of the ear was higher than that of the flag leaf [2]. Nevertheless, in another study (but with detached organs), the gas exchange did not show a clearly higher TE in the ear than in the flag leaf [5]. Moreover, few studies have compared the two organs under different levels of water stress [6]. The high level of respiration of the ears substantially affects (decreasing) net photosynthesis and thus the TE of the ears [2]. However, this respiration is due at least in part to growing kernels and not produced by the photosynthetic tissues of the ear. Therefore the real photosynthetic activity and TE of the ear is actually much higher than that traditionally measured [2] and probably part of the $\mathrm{CO}_{2}$ respired is refixed by the ear [8].

Here we study the effect of the water regime and genotype on the photosynthetic capacity and the TE of the ear and the flag leaf. The relative contribution of each organ to yield is assessed for each water regime via the relationship between the gas exchange properties of each organ and yield.

\section{MATERIALS AND METHODS}

\subsection{Plant material and growing conditions}

The study was performed on six durum wheat (Triticum turgidum L. var. durum) genotypes. Four were local varieties traditionally cultivated in arid and semiarid areas of South Morocco and the other two were cultivars released by the Moroccan Institut National de la Recherche Agronomique (INRA), that are adapted to semiarid conditions. These represent a wide range of variation in the shape and the size of the ear and the flag leaf blade (Tab. I).

Plants were grown in pots in a temperature-controlled greenhouse located in the experimental fields of the Universitat de Barcelona, spring 1999. Two-litre pots, $170 \mathrm{~mm}$ in diameter, were filled with a $3: 1(\mathrm{v} / \mathrm{v})$ mixture of peat and per- lite and seeded with three plants each. After plant emergence, pots were irrigated at field capacity once every two days, alternating distilled water and a nutritive solution. When the plants reached booting (corresponding to stage 43 of the Zadoks [31] decimal code) five different water regimes were imposed and maintained until maturity (stage 87). They consisted of $100 \%$ (control), 60\%, 40\%, 20\% and 10\% of maximum pot water capacity. For each water treatment the content of the substrate was monitored according to Sinclair and Ludlow [24]: pots were weighed every day and plants were watered by hand. A factorial combination of the six genotypes and five water regimes was arranged in a complete random block design with three replications, each pot being an experimental unit. For each pot the whole shoot biomass of one plant was sampled at maturity, oven-dried $\left(70{ }^{\circ} \mathrm{C}\right)$ and then weighed. Grains were further harvested and then weighed.

\subsection{Gas exchange and water status}

For each pot, gas exchange was measured on the intact ear (including awns) and the flag leaf blade of the main tiller of one plant (the same plant later sampled at maturity). A portable Infra-Red Gas Analyser (IRGA) LI-6200 (LI-COR In, Lincoln, Nebraska, USA) was used, functioning in closed mode for $30 \mathrm{~s}$ per sample. The traits measured were net $\mathrm{CO}_{2}$ assimilation at light saturation (net photosynthesis rate, A) plus transpiration $(\mathrm{T})$ rates and then stomatal conductance $\left(\mathrm{g}_{\mathrm{s}}\right)$ and the intercellular $\mathrm{CO}_{2}$ concentration were calculated after von Caemmerer and Farquhar [29]. A gas exchange chamber designed to contain the whole organ was used for the ear, and a standard leaf chamber was used for the blade. Measurements were performed on sunny days (above $1000 \mathrm{~mol} \mathrm{~m}^{-2} \mathrm{~s}^{-1}$ PPFD) at anthesis (stage 69), between 10.00 a.m. and 1.30 p.m. (solar time), by holding the chamber perpendicular to the incident light from the sun. Organ temperature during measurement ranged from $22-26{ }^{\circ} \mathrm{C}$. Gas exchange rates were calculated either per unit area or for the whole organ. For calculations, the area of the ear (including the awns) was assimilated to a rightangled parallelepiped. Transpiration efficiency (TE) was calculated as the ratio between net photosynthesis and transpiration rates. In addition, the ratio between $\mathrm{A}$ and $\mathrm{g}_{\mathrm{s}}$ was also calculated to prevent the effect of a different vapour pressure deficit (which ranged between 0.85 and $1.07 \mathrm{kPa}$ ) during gas exchange measurements on transpiration rates.

Relative water content (RWC) was measured on the same leaves used for gas exchange measurements as RWC $=(\mathrm{FM}-$ $\mathrm{DM}) /(\mathrm{TM}-\mathrm{DM}) \times 100$, where FM, TM and DM are fresh, turgid, and dry mass of the leaf.

\section{RESULTS}

Water regime had a significant effect on plant shoot biomass (SPB) and grain yield (GYP) per plant, and also on the relative water content (RWC) of the flag leaf and all the gas-exchange traits measured in the flag leaf and the ear (Tabs. II and III). The mean squares of the water treatment were greater than those of the genotype (except for flag leaf A/T). However, the genotype effect was still highly significant for all the traits. The relative effect of genotype on gas exchange traits on a wholeorgan basis was similar in the ear and in the flag leaf. Genotype 
Table I. Name, place of collection, and comparative morphological characteristics of the ear and the flag leaf of the 6 Moroccan durum wheat genotypes used in this study. Size of ears and flag leaves corresponds to the pot plants grown in this study at full pot capacity (100\% ASW).

\begin{tabular}{|c|c|c|c|c|c|c|}
\hline Genotype name & $\begin{array}{l}\text { Locality of } \\
\text { collection }\end{array}$ & Ear shape and bract colour & Awn colour & $\begin{array}{c}\text { Ear length: bracts } \\
- \text { bracts }+ \text { awns }(\mathrm{cm})\end{array}$ & Ear width $(\mathrm{cm})$ & Flag leaf area $\left(\mathrm{cm}^{2}\right)$ \\
\hline Lbyed & Lkbeb & Fairly flattened, yellow & White-Pale green & $9.0-14.0$ & 1.5 & 20.9 \\
\hline Boubter & Oulmes & Rectangular, russet-red, smooth & Black & $10.5-15.5$ & 2 & 19.0 \\
\hline Lharcha & Ouazzane & Curved, shaggy, yellow & Black & $11.5-17.5$ & 2.7 & 22.5 \\
\hline Maazouzia & Taza & Fairly flattened, pale yellow & White-Pale green & $11.5-14.5$ & 2.8 & 23.5 \\
\hline Sarif & INRA collection & Rectangular, pale yellow, smooth & White-Pale green & $7.0-13.0$ & 1.4 & 16.9 \\
\hline Sebou & INRA collection & Rectangular, yellow, smooth & White-Pale green & $8.0-13.5$ & 1.6 & 19.2 \\
\hline
\end{tabular}

Table II. Combined analysis of variance showing the mean squares of the genotype and treatment factors and the interaction genotype $\times$ treatment for the relative water content of the flag leaf (RWC), shoot biomass (SBP) and grain yield per plant (GYP) and the net photosynthesis (A), transpiration $(\mathrm{T})$, stomatal conductance $\left(\mathrm{g}_{\mathrm{s}}\right)$ and the ratio of intercellular versus external $\mathrm{CO}_{2}$ concentration $\left(\mathrm{C}_{\mathrm{i}} / \mathrm{C}_{\mathrm{a}}\right)$ measured in the flag leaf.

\begin{tabular}{|c|c|c|c|c|c|c|c|c|c|c|}
\hline $\begin{array}{l}\text { Source of } \\
\text { variation }\end{array}$ & RWC (\%) & $\begin{array}{l}\text { SBP }(g \\
\left.\text { plant }^{-1}\right)\end{array}$ & $\begin{array}{l}\text { GYP (g } \\
\left.\text { plant }^{-1}\right)\end{array}$ & $\begin{array}{c}\mathrm{g}_{\mathrm{s}}\left(\mathrm{mol} \mathrm{CO} \mathrm{CO}_{2}\right. \\
\left.\mathrm{m}^{-2} \mathrm{~s}^{-1}\right)\end{array}$ & $\begin{array}{c}\mathrm{A}\left(\mu \mathrm{mol} \mathrm{CO} \mathrm{CO}_{2}\right. \\
\left.\mathrm{m}^{-2} \mathrm{~s}^{-1}\right)\end{array}$ & $\begin{array}{c}\mathrm{A}\left(\mathrm{nmol} \mathrm{CO}_{2}\right. \\
\left.\operatorname{organ}^{-1} \mathrm{~s}^{-1}\right)\end{array}$ & $\begin{array}{c}\mathrm{A} / \mathrm{g}_{\mathrm{s}}(\mu \mathrm{mol} \\
\left.\mathrm{mol}^{-1}\right)\end{array}$ & $\mathrm{C}_{\mathrm{i}} / \mathrm{C}_{\mathrm{a}}$ & $\begin{array}{c}\mathrm{T}\left(\mathrm{mmol} \mathrm{H} \mathrm{H}_{2} \mathrm{O}\right. \\
\left.\mathrm{m}^{-2} \mathrm{~s}^{-1}\right)\end{array}$ & $\begin{array}{c}\mathrm{A} / \mathrm{T}\left(\mathrm{mmol} \mathrm{CO}_{2}\right. \\
\left.\mathrm{mol} \mathrm{H}_{2} \mathrm{O}^{-1}\right)\end{array}$ \\
\hline Water regime & e $8134.13 * * *$ & $255.16^{* * * * *}$ & $45.98 * * *$ & $0.38 * * *$ & $938.21 * * *$ & $3075.27 * * *$ & $58402.60 * * *$ & $0.505^{* * *}$ & $111.34 * * *$ & $4.862 * * *$ \\
\hline Genotype & $1149.34 * * *$ & $118.06^{* * *}$ & $1.73 * * *$ & $0.15^{* * *}$ & $221.00 * * *$ & $744.99 * * *$ & $2342.47 * * *$ & $0.150 * * *$ & $17.37 * * *$ & $13.36 * * *$ \\
\hline $\begin{array}{l}\text { Genotype } \times \\
\text { Treatment }\end{array}$ & $37.16^{* *}$ & $9.55 * * *$ & $0.06 * *$ & $0.03 * * *$ & $7.58 * * *$ & $76.67 * * *$ & $15404.24 * * *$ & $0.015^{* * *}$ & $8.00 * * *$ & $2.05 * * *$ \\
\hline Error & 15.28 & 1.05 & 0.02 & 0.004 & 1.70 & 11.57 & 3677.44 & 0.004 & 1.88 & 0.18 \\
\hline
\end{tabular}

***,***: significant at $P<0.05,0.01,0.001$, respectively.

Table III. Combined analysis of variance showing the mean squares of the genotype and treatment factors and the interaction genotype $\times$ treatment for the net photosynthesis (A), transpiration (T), stomatal conductance $\left(\mathrm{g}_{\mathrm{s}}\right)$ and the ratio of intercellular versus external $\mathrm{CO}_{2}$ concentration $\left(\mathrm{C}_{\mathrm{i}} / \mathrm{C}_{\mathrm{a}}\right)$ measured in the ear.

\begin{tabular}{|c|c|c|c|c|c|c|c|}
\hline Source of variation & $\begin{array}{c}\mathrm{g}_{\mathrm{s}}\left(\mathrm{mol} \mathrm{CO} \mathrm{CO}_{2}\right. \\
\left.\mathrm{m}^{-2} \mathrm{~s}^{-1}\right)\end{array}$ & $\begin{array}{c}\mathrm{A}\left(\mu \mathrm{mol} \mathrm{CO} \mathrm{CO}_{2}\right. \\
\left.\mathrm{m}^{-2} \mathrm{~s}^{-1}\right)\end{array}$ & $\begin{array}{c}\mathrm{A}\left(\mathrm{nmol} \mathrm{CO} \mathrm{CO}_{2}\right. \\
\left.\operatorname{organ}^{-1} \mathrm{~s}^{-1}\right)\end{array}$ & $\begin{array}{c}\mathrm{A} / \mathrm{g}_{\mathrm{s}} \\
\left(\mu \mathrm{mol} \mathrm{\textrm {mol } ^ { - 1 }}\right)\end{array}$ & $\mathrm{C}_{\mathrm{i}} / \mathrm{C}_{\mathrm{a}}$ & $\begin{array}{c}\mathrm{T} \\
\left(\mathrm{mmol} \mathrm{H} \mathrm{O}_{2} \mathrm{O}^{-2} \mathrm{~s}^{-1}\right)\end{array}$ & $\begin{array}{c}\mathrm{A} / \mathrm{T}(\mathrm{mmol} \\
\left.\mathrm{CO}_{2} \mathrm{~mol} \mathrm{H}_{2} \mathrm{O}^{-1}\right)\end{array}$ \\
\hline Water regime & $1.26 * * *$ & $1095.70 * * *$ & $49010.20 * * *$ & $26083.61 * * *$ & $0.500 * * *$ & $210.90 * * *$ & $25.41 * * *$ \\
\hline Genotype & $0.07 * * *$ & $14.66 * * *$ & $948.10 * * *$ & $14200.93 * * *$ & $0.103 * * *$ & $5.64 * * *$ & $0.63 * * *$ \\
\hline Genotype $\times$ water regime & $0.008 * * *$ & $1.32 *$ & $84.59 * * *$ & $2430.64 * * *$ & $0.005 * * *$ & $0.22 * * *$ & 0.13 \\
\hline Error & 0.000 & 0.66 & 7.89 & 263.94 & 0.000 & 0.03 & 0.08 \\
\hline
\end{tabular}

***,***: significant at $P<0.05,0.01,0.001$, respectively.

by treatment interaction was also significant in all cases. However, the mean squares of the interactions were much lower than those of water treatment and genotype, which means the average of treatments is still informative (Tabs. IV and V). Relative water content ranged from around $87 \%$ to $40 \%$, shoot biomass was between $20 \mathrm{~g}$ and $12 \mathrm{~g}$ and grain yield between $6.2 \mathrm{~g}$ and $2.5 \mathrm{~g}$ for plants growing in $100 \%$ (full pot capacity) and $10 \%$ of available soil water (ASW), respectively (Tab. IV). Net photosynthesis (A), stomatal conductance $\left(\mathrm{g}_{\mathrm{s}}\right)$ and transpiration (T) values per unit area of flag leaves decreased around five-, fifteen- and three-fold, respectively, whereas the ratio $\mathrm{A} / \mathrm{g}_{\mathrm{s}}$ doubled from $100 \%$ to $10 \% \mathrm{ASW}$. The ratio $\mathrm{A} / \mathrm{T}$ remained quite steady from $100 \%$ to $20 \% \mathrm{ASW}$, and then decreased at $10 \%$ ASW (Tab. IV). In the ear, from $100 \%$ to $10 \%$ ASW, A, $\mathrm{g}_{\mathrm{s}}$, and $\mathrm{T}$ per unit area decreased about 3, 15 and 3 times whereas $\mathrm{A} / \mathrm{g}_{\mathrm{s}}$ increased 5 times, respectively. The $\mathrm{A} / \mathrm{T}$ ratio almost doubled from $100 \%$ to $20 \%$ ASW, but decreased at $10 \%$ ASW (Tab. V). The ratio of atmospheric to intercellular $\mathrm{CO}_{2}$ concentration $\left(\mathrm{C}_{\mathrm{i}} / \mathrm{C}_{\mathrm{a}}\right)$ decreased in both organs from $100 \%$ to $40 \% \mathrm{ASW}$, increasing again at $10 \% \mathrm{ASW}$ to values close to those at full pot capacity. For both organs the decrease in wholeorgan photosynthesis from $100 \%$ to $10 \%$ ASW was ten- and eight-fold for the leaf and the ear, respectively. Such a decrease is larger than that of the photosynthesis rate per unit area and reflects the changes in organ size as affected by water regime. For each water regime there were significant differences across genotypes for almost all the traits (Tabs. VI and VII). Lharcha and Boubter were the genotypes showing the highest and lowest shoot biomass, respectively, across all the water regimes. The two cultivars from INRA (Sarif and Sebou) showed an intermediate performance. Whereas, at full pot capacity, Maazouzia and Lharcha were the genotypes showing the highest and lowest grain yield, respectively, among the 6 genotypes assayed the opposite effect was observed in the most stressed water treatment (10\% ASW). By contrast, Boubter showed good grain yield across all the water regimes assayed and the two cultivars of INRA showed fairly good grain yield in the intermediate water regimes. Lharcha was the genotype showing the highest rates of ear and flag leaf photosynthesis (either on an area basis or per whole organ) across all the water 
Table IV. Effect of water regime on the relative water content of the flag leaf (RWC), shoot biomass (SBP), and grain yield per plant (GYP), and the net photosynthesis $(A)$, transpiration $(T)$, stomatal conductance $\left(\mathrm{g}_{\mathrm{s}}\right)$ and the ratio of intercellular versus external $\mathrm{CO}_{2}$ concentration $\left(\mathrm{C}_{\mathrm{i}} / \mathrm{C}_{\mathrm{a}}\right)$ measured in the flag leaf. Values presented are means \pm SE for the set of 6 genotypes under the different water regimes. Within columns, means followed by the same letter are not significantly different according to the t-test (least significant difference, $P<0.05$ ).

\begin{tabular}{|c|c|c|c|c|c|c|c|c|c|}
\hline RWC (\%) & $\begin{array}{c}\text { SBP } \\
\left(\text { g plant }^{-1}\right)\end{array}$ & $\begin{array}{c}\text { GYP } \\
\left(\mathrm{g} \mathrm{plant}^{-1}\right)\end{array}$ & $\begin{array}{c}\mathrm{g}_{\mathrm{s}}\left(\mathrm{mol} \mathrm{CO} \mathrm{CO}_{2}\right. \\
\left.\mathrm{m}^{-2} \mathrm{~s}^{-1}\right)\end{array}$ & $\begin{array}{c}\mathrm{A}\left(\mu \mathrm{mol} \mathrm{CO} \mathrm{CO}_{2}\right. \\
\left.\mathrm{m}^{-2} \mathrm{~s}^{-1}\right)\end{array}$ & $\begin{array}{c}\mathrm{A}\left(\mathrm{nmol} \mathrm{CO}{ }_{2}\right. \\
\left.\operatorname{organ}^{-1} \mathrm{~s}^{-1}\right)\end{array}$ & $\begin{array}{c}\mathrm{A} / \mathrm{g}_{\mathrm{s}} \\
\left(\mu \mathrm{mol} \mathrm{mol}^{-1}\right)\end{array}$ & $\mathrm{C}_{\mathrm{i}} / \mathrm{C}_{\mathrm{a}}$ & $\begin{array}{c}\mathrm{T}\left(\mathrm{mmol} \mathrm{H}_{2} \mathrm{OA}\right. \\
\left.\mathrm{m}^{-2} \mathrm{~s}^{-1}\right)\end{array}$ & $\begin{array}{c}\mathrm{A} / \mathrm{T}\left(\mathrm{mmol} \mathrm{CO}_{2}\right. \\
\left.\mathrm{mol} \mathrm{H}_{2} \mathrm{O}^{-1}\right)\end{array}$ \\
\hline \multicolumn{10}{|l|}{ Water regime (ASW) } \\
\hline $100 \% 86.96^{\mathrm{d}} \pm 1.63$ & $20.23^{\mathrm{d}} \pm 1.19$ & $6.23^{\mathrm{e}} \pm 0.09$ & $0.37^{\mathrm{c}} \pm 0.04$ & $23.95^{\mathrm{e}} \pm 0.60$ & $37.61^{\mathrm{e}} \pm 3.04$ & $88.94^{\mathrm{a}} \pm 13.09$ & $0.67^{\mathrm{d}} \pm 0.03$ & $7.91^{c} \pm 0.38$ & $2.69^{\mathrm{b}} \pm 0.13$ \\
\hline $60 \% \quad 79.37^{\mathrm{c}} \pm 1.92$ & $18.32^{\mathrm{c}} \pm 0.84$ & $5.92^{\mathrm{d}} \pm 0.08$ & $0.31^{\mathrm{bc}} \pm 0.04$ & $16.38^{\mathrm{d}} \pm 0.96$ & $22.75^{\mathrm{d}} \pm 2.34$ & $80.14^{\mathrm{a}} \pm 17.64$ & $0.59^{\mathrm{c}} \pm 0.02$ & $7.85^{\mathrm{c}} \pm 0.36$ & $1.94^{\mathrm{a}} \pm 0.22$ \\
\hline $40 \% \quad 61.34^{b} \pm 2.03$ & $15.25^{\mathrm{b}} \pm 0.71$ & $3.92^{\mathrm{c}} \pm 0.10$ & $0.25^{\mathrm{b}} \pm 0.03$ & $14.60^{\mathrm{c}} \pm 1.19$ & $17.19^{\mathrm{c}} \pm 1.81$ & $72.87^{\mathrm{a}} \pm 8.73$ & $0.32^{\mathrm{a}} \pm 0.03$ & $5.58^{\mathrm{b}} \pm 0.57$ & $2.62^{\mathrm{b}} \pm 0.39$ \\
\hline $20 \% \quad 42.26^{\mathrm{a}} \pm 2.52$ & $12.13^{\mathrm{a}} \pm 0.38$ & $3.46^{\mathrm{b}} \pm 0.05$ & $0.09^{\mathrm{a}} \pm 0.02$ & $10.27^{\mathrm{b}} \pm 1.21$ & $9.67^{b} \pm 1.13$ & $157.31^{\mathrm{b}} \pm 26.52$ & $0.38^{\mathrm{b}} \pm 0.05$ & $3.41^{\mathrm{a}} \pm 0.68$ & $3.02^{b} \pm 0.40$ \\
\hline $10 \% \quad 39.79^{\mathrm{a}} \pm 2.72$ & $11.63^{\mathrm{a}} \pm 0.39$ & $2.54^{\mathrm{a}} \pm 0.09$ & $0.03^{\mathrm{a}} \pm 0.00$ & $4.54^{\mathrm{a}} \pm 0.52$ & $3.64^{\mathrm{a}} \pm 0.39$ & $202.54^{\mathrm{b}} \pm 22.44$ & $0.68^{\mathrm{d}} \pm 0.01$ & $2.50^{\mathrm{a}} \pm 0.33$ & $1.81^{\mathrm{a}} \pm 0.10$ \\
\hline
\end{tabular}

Table V. Effect of water regime on the net photosynthesis $(\mathrm{A})$, transpiration $(\mathrm{T})$, stomatal conductance $\left(\mathrm{g}_{\mathrm{s}}\right)$ and the ratio of intercellular versus external $\mathrm{CO}_{2}$ concentration $\left(\mathrm{C}_{\mathrm{i}} / \mathrm{C}_{\mathrm{a}}\right)$ of the ear. Values presented are means $\pm \mathrm{SE}$ for the set of 6 genotypes under the different water regimes. Within columns, means followed by the same letter are not significantly different according to the t-test (least significant difference, $P<0.05$ ).

\begin{tabular}{|c|c|c|c|c|c|c|c|}
\hline & $\begin{array}{c}\mathrm{g}_{\mathrm{s}} \\
\left(\mathrm{mol} \mathrm{CO} 2 \mathrm{~m}^{-2} \mathrm{~s}^{-1}\right)\end{array}$ & $\begin{array}{c}\mathrm{A} \\
\text { umol } \mathrm{CO}_{2} \mathrm{~m}^{-2} \mathrm{~s}^{-1} \text { ) }\end{array}$ & $\begin{array}{c}\mathrm{A}\left(\mathrm{nmol} \mathrm{CO} \mathrm{CO}_{2}\right. \\
\left.\operatorname{organ}^{-1} \mathrm{~s}^{-1}\right)\end{array}$ & $\mathrm{A} / \mathrm{g}_{\mathrm{s}}\left(\mu \mathrm{mol} \mathrm{mol}{ }^{-1}\right)$ & $\mathrm{C}_{\mathrm{i}} / \mathrm{C}_{\mathrm{a}}$ & $\begin{array}{c}\mathrm{T}(\mathrm{mmol} \\
\left.\mathrm{H}_{2} \mathrm{O} \mathrm{m}^{-2} \mathrm{~s}^{-1}\right)\end{array}$ & $\begin{array}{c}\mathrm{A} / \mathrm{T}(\mathrm{mmol} \\
\left.\mathrm{CO}_{2} \mathrm{~mol} \mathrm{H}_{2} \mathrm{O}^{-1}\right)\end{array}$ \\
\hline \multicolumn{8}{|c|}{ Water regime (ASW) } \\
\hline $100 \%$ & $0.61^{\mathrm{e}} \pm 0.03$ & $30.26^{\mathrm{e}} \pm 0.20$ & $147.67^{\mathrm{e}} \pm 2.04$ & $50.96^{\mathrm{a}} \pm 1.95$ & $0.83^{\mathrm{e}} \pm 0.02$ & $10.54^{\mathrm{e}} \pm 0.16$ & $2.88^{\mathrm{b}} \pm 0.03$ \\
\hline $60 \%$ & $0.56^{\mathrm{d}} \pm 0.02$ & $27.23^{\mathrm{d}} \pm 0.37$ & $122.10^{\mathrm{d}} \pm 3.26$ & $49.49^{\mathrm{a}} \pm 1.45$ & $0.78^{\mathrm{c}} \pm 0.03$ & $10.23^{\mathrm{d}} \pm 0.19$ & $2.67^{\mathrm{a}} \pm 0.03$ \\
\hline $40 \%$ & $0.34^{\mathrm{c}} \pm 0.02$ & $26.42^{\mathrm{c}} \pm 0.26$ & $101.24^{\mathrm{c}} \pm 1.70$ & $84.50^{b} \pm 6.72$ & $0.50^{\mathrm{a}} \pm 0.01$ & $7.12^{\mathrm{c}} \pm 0.17$ & $3.74^{\mathrm{d}} \pm 0.07$ \\
\hline $20 \%$ & $0.071^{\mathrm{b}} \pm 0.028$ & $20.86^{\mathrm{b}} \pm 0.39$ & $52.13^{\mathrm{b}} \pm 2.02$ & $302.96^{\mathrm{d}} \pm 9.54$ & $0.52^{\mathrm{b}} \pm 0.02$ & $3.76^{\mathrm{b}} \pm 0.11$ & $5.61^{\mathrm{e}} \pm 1.14$ \\
\hline $10 \%$ & $0.045^{\mathrm{a}} \pm 0.003$ & $10.48^{a} \pm 0.26$ & $19.40^{\mathrm{a}} \pm 0.92$ & $251.11^{\mathrm{c}} \pm 17.33$ & $0.82^{\mathrm{d}} \pm 0.02$ & $3.35^{\mathrm{a}} \pm 0.09$ & $3.14^{\mathrm{c}} \pm 0.07$ \\
\hline
\end{tabular}

regimes. Albeit less markedly, Boubter was the genotype showing the lowest rates of ear photosynthesis (on both an area and whole-organ basis) and flag leaf photosynthesis (but only per unit leaf area).

\subsection{Photosynthetic performance of the ear versus the flag leaf}

The rate of photosynthesis per unit area at full pot capacity was about $25 \%$ higher in the ear than in the flag leaf (Tabs. IV and V). These differences may be due to differences in what is considered as a photosynthetic area in each organ (only one side in the leaf and the entire area of a right-angled parallelepiped in the ear) and to the intrinsic difficulties associated with the shape of the ear. However, when expressed per whole organ, the rate of ear photosynthesis was four times higher than that of the flag-leaf blade at full pot capacity. Moreover, under water stress the photosynthesis of the ear relative to that of the leaf increased over 6 times at $40 \%$ ASW, remaining fairly stable in the range 40-10\% ASW (Fig. 1a). Within each water regime the range of variability in the photosynthesis rate either per unit area or per whole organ was much larger in the leaf than in the ear (Tabs. IV, V, VI and VII). Also, the effect of genotypic variability relative to that of water regime was much higher for the leaf than for the ear photosynthesis (Tabs. II and III).

The $\mathrm{A} / \mathrm{g}_{\mathrm{s}}$ ratio was somewhat smaller in the ear than in the flag leaf at full pot capacity, but this tendency reversed as the level of water stress increased (Fig. 1b). The A/T ratio was similar for both organs at full pot capacity, then increasing relatively more in the ear than in the flag leaf as the level of water stress increased, attaining values 3 times higher in the former at $20 \%$ ASW (Fig. 1c).

\subsection{Relationship of the photosynthetic activity with plant shoot biomass and yield}

When expressed on an area basis, the photosynthesis rates of the flag leaf correlated in general better than those of the ear with plant shoot biomass (SPB) for each water regime: from 100 to $10 \%$ ASW the determination coefficients $\left(\mathrm{r}^{2}\right)$ of the relationships $(\mathrm{n}=18)$ were $0.28,0.63,0.45,0.63$ and 0.93 for the flag leaf and $0.68,0.61,0.11,0.33$ and 0.47 for the ear, respectively. However, the relationship between SPB and the whole-ear photosynthesis was very high regardless of the water regime considered (Fig. 2a): the slope of the relationship remained fairly steady in the different water regimes, with the line of each relationship being different. In contrast, the photosynthesis of the whole flag leaf blade was weakly correlated at full pot capacity (Fig. 2b), but increased progressively as water stress increased $\left(r^{2}=0.75\right.$ at $10 \%$ ASW $)$, although it was lower than that attained by the ear $\left(\mathrm{r}^{2}=0.87\right.$ at $10 \%$ ASW). Similarly, as for the ear, the slope of the relationship increased from $100 \%$ ASW to $10 \%$ ASW, but the line of each relationship did not shift.

The $\mathrm{A} / \mathrm{g}_{\mathrm{s}}$ ratio in the ear correlated negatively with SPB for all the water regimes (Fig. 3a). Considering all the water regimes together the relationship was non-linear. Although the relationship was stronger at full pot capacity, it remained fairly steady at the different levels of water stress. The slope of the relationship increased as the water limitation decreased. The flag leaf showed a weaker relationship with shoot biomass than the ear, independent of the water treatment considered (Fig. 3b). Similar to the ear, the relationship was also negative at full pot capacity, the strength of the relationship decreasing as the level of water stress increased. On the other hand, the slope of the negative relationship decreased as the water limitation 


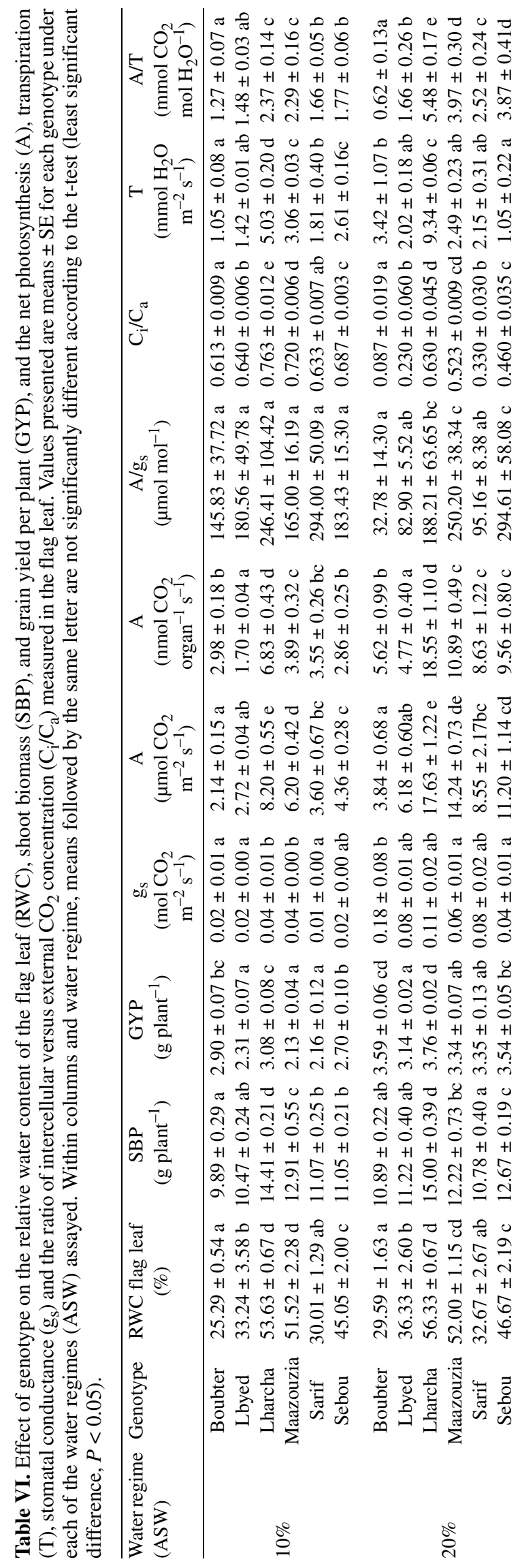

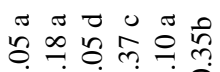

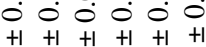

大



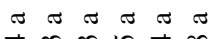

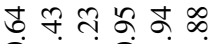

$+1+1+1+1+1$

ฑิ

nरrषin

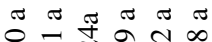



$\begin{array}{llll}2 & +1 \\ +1 & +1 & +1 & +1\end{array}$

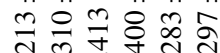

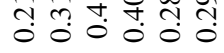

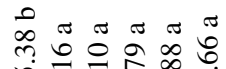

ป

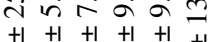

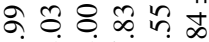

in 齐 in

ส

กิํํำ

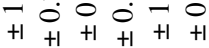

สำ ํํํ

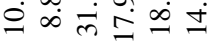

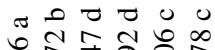

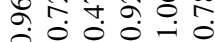

$\begin{array}{llllll}0 & 0 & 0 & 0 & -1 & 0 \\ 0 & +1 & +1 & +1 & +1 & +1\end{array}$

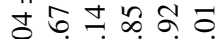

$\therefore \circ \dot{0} \infty$

ส

든은 ㄴำ

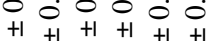

\% पे जิ

०० 0

의



동ำ

$0 \leqslant \infty$ i

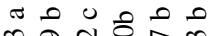

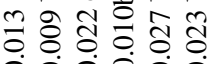

00000

$+1+1+1+1+1+1$

유ำํํำ

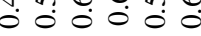

ค

뭉ำ 시용

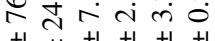



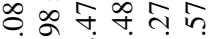



สิ ๘ 0 สิ

$8 \%$ 늉ำ

$\begin{array}{llllll}+ & 0 & \infty & 0 & 0 & 0 \\ +1 & +1 & +1 & +1 & +1 & +1\end{array}$

8 to $\infty$ in 8

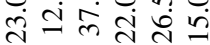

$\pi=0 \nabla 00$

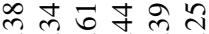

000000

$+1+1+1+1+1+$

б $\forall \hat{b}$ in

$=$ ต่ป

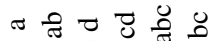

○.

$\pi$ ती 0 ० 0

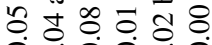

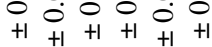

$+1+1+1+1+1$

ڤึ)

$\exists$ च.



ป̂.

$+1+1+1+1+1+$

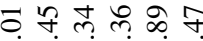

的

î.

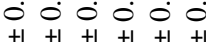

สี

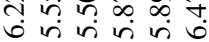

$\pi \pi \rho \pi \pi \pi$ a $\pi \tau 000$

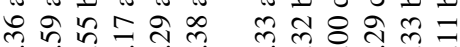

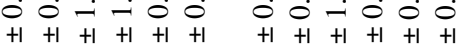

$\hat{\alpha}=\infty 8$ กิ

ปท่

m $\pm \hat{\sigma}$

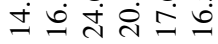

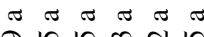

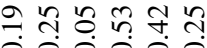

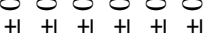

के पुल केष

त त $\mathrm{d}$ m

ส

วิ $\pm \hat{0}$ ㄴำ

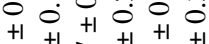

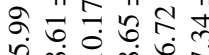

ส

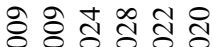

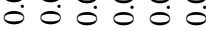

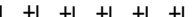

m

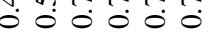

ํํㅇ



m m $\mathrm{m}$ i 2

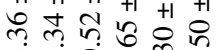

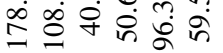

\%



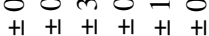

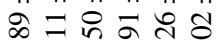



$\pi \approx 0000$ กิ

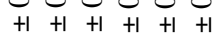
范方 तิ กิ่

त की० 00 ปี

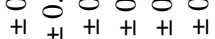
즈ำ ำ ส $20 \% 0$ กิ

ส

m ลे तิ

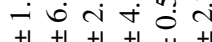

ธิธ

i

लㅈำ 000000

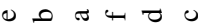

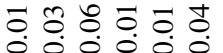
$+1+1+1+1$ 윤ํㄷㄴ o in

ส $\pi 000$ 그음 $00 \dot{0}-\dot{0} 00$ ป⿻ำ 드워으

ช० $0 \approx 0 \%$

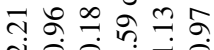

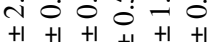
च चั

성 in in

نे

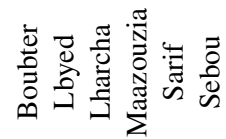

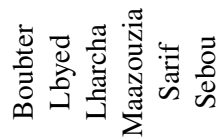

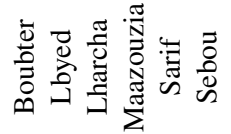


Table VII. Effect of genotype on the net photosynthesis (A), transpiration (T), stomatal conductance $\left(\mathrm{g}_{\mathrm{s}}\right)$ and the ratio of intercellular versus external $\mathrm{CO}_{2}$ concentration $\left(\mathrm{C}_{\mathrm{i}} / \mathrm{C}_{\mathrm{a}}\right)$ measured in the ear. Values presented are means $\pm \mathrm{SE}$ for each genotype under each of the water regimes (ASW) assayed. Within columns and water regime, means followed by the same letter are not significantly different according to the t-test (least significant difference, $P<0.05$ ).

\begin{tabular}{|c|c|c|c|c|c|c|c|c|}
\hline $\begin{array}{l}\text { Water } \\
\text { regime } \\
\text { (ASW) } \\
\end{array}$ & Genotype & $\begin{array}{c}\mathrm{g}_{\mathrm{s}} \\
(\mathrm{mol} \mathrm{CO} 2 \\
\left.\mathrm{m}^{-2} \mathrm{~s}^{-1}\right)\end{array}$ & $\begin{array}{c}\mathrm{A} \\
\left(\mu \mathrm{mol} \mathrm{CO} \mathrm{CO}_{2}\right. \\
\left.\mathrm{m}^{-2} \mathrm{~s}^{-1}\right)\end{array}$ & $\begin{array}{c}\mathrm{A} \\
\left(\mathrm{nmol} \mathrm{CO}_{2}\right. \\
\left.\text { organ }^{-1} \mathrm{~s}^{-1}\right)\end{array}$ & 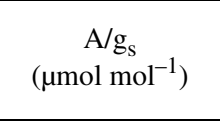 & $\mathrm{C}_{\mathrm{i}} / \mathrm{C}_{\mathrm{a}}$ & $\begin{array}{c}\mathrm{T} \\
\left(\mathrm{mmol} \mathrm{\textrm {H } _ { 2 } \mathrm { O }}\right. \\
\left.\mathrm{m}^{-2} \mathrm{~s}^{-1}\right)\end{array}$ & $\begin{array}{c}\mathrm{A} / \mathrm{T} \\
\left(\mathrm{mmol} \mathrm{CO} \mathrm{CO}_{2}\right. \\
\left.\mathrm{mol} \mathrm{H}_{2} \mathrm{O}^{-1}\right)\end{array}$ \\
\hline \multirow{6}{*}{$10 \%$} & Boubter & $0.03 \pm 0.00 \mathrm{a}$ & $9.22 \pm 0.33 \mathrm{a}$ & $14.85 \pm 1.31 \mathrm{a}$ & $357.26 \pm 17.60 \mathrm{~b}$ & $0.720 \pm 0.006 \mathrm{a}$ & $2.93 \pm 0.05 \mathrm{a}$ & $3.15 \pm 0.16 \mathrm{ab}$ \\
\hline & Lbyed & $0.03 \pm 0.00 \mathrm{~b}$ & $10.98 \pm 0.24 b$ & $18.66 \pm 0.09 \mathrm{bc}$ & $328.51 \pm 23.65 b$ & $0.787 \pm 0.003 \mathrm{bc}$ & $0.01 \mathrm{~b}$ & $0.06 \mathrm{~b}$ \\
\hline & Lharcha & $0.06 \pm 0.00 \mathrm{e}$ & $11.78 \pm 0.35 b$ & $26.13 \pm 1.14 \mathrm{~d}$ & $183.68 \pm 8.49 \mathrm{a}$ & $0.963 \pm 0.015 \mathrm{e}$ & $4.03 \pm 0.01 \mathrm{e}$ & $2.92 \pm 0.08 \mathrm{a}$ \\
\hline & Maazouzia & $0.06 \pm 0.00 \mathrm{~d}$ & $10.82 \pm 0.10 b$ & $21.14 \pm 0.46 \mathrm{c}$ & $200.99 \pm 9.79 \mathrm{a}$ & $0.883 \pm 0.015 \mathrm{~d}$ & $3.53 \pm 0.04 \mathrm{~d}$ & $3.07 \pm 0.02 \mathrm{a}$ \\
\hline & Sarif & $0.04 \pm 0.00 \mathrm{c}$ & $9.34 \pm 0.78 \mathrm{a}$ & $17.55 \pm 1.24 \mathrm{ab}$ & $232.43 \pm 26.68 \mathrm{a}$ & $0.763 \pm 0.012 \mathrm{~b}$ & $3.20 \pm 0.01 \mathrm{c}$ & $2.92 \pm 0.24 \mathrm{a}$ \\
\hline & Sebou & $0.05 \pm 0.00 \mathrm{~d}$ & $10.76 \pm 0.35 b$ & $18.07 \pm 0.99 \mathrm{bc}$ & $203.30 \pm 4.86 \mathrm{a}$ & $0.803 \pm 0.003 \mathrm{c}$ & $3.28 \pm 0.02 \mathrm{c}$ & $3.28 \pm 0.09 \mathrm{ab}$ \\
\hline \multirow{6}{*}{$20 \%$} & Boubter & $0.06 \pm 0.00 \mathrm{a}$ & $19.34 \pm 0.35 a$ & $45.50 \pm 1.15 \mathrm{a}$ & $347.97 \pm 12.27 \mathrm{c}$ & $0.430 \pm 0.006 \mathrm{a}$ & $3.06 \pm 0.03 \mathrm{a}$ & $6.32 \pm 0.11 \mathrm{a}$ \\
\hline & Lbyed & $0.06 \pm 0.00 \mathrm{~b}$ & $21.25 \pm 0.48 \mathrm{abc}$ & $52.07 \pm 1.25 \mathrm{~b}$ & $344.92 \pm 12.19 \mathrm{c}$ & $0.460 \pm 0.006 \mathrm{~b}$ & $4.00 \pm 0.30 \mathrm{bc}$ & $0.55 \mathrm{a}$ \\
\hline & Lharcha & $0.09 \pm 0.00 \mathrm{e}$ & $22.96 \pm 0.34 \mathrm{c}$ & $67.31 \pm 0.94 \mathrm{c}$ & $255.24 \pm 3.47 \mathrm{a}$ & $0.643 \pm 0.009 \mathrm{e}$ & $4.29 \pm 0.02 \mathrm{c}$ & $5.35 \pm 0.08 \mathrm{a}$ \\
\hline & Maazouzia & $0.08 \pm 0.00 \mathrm{~d}$ & $20.34 \pm 1.00 \mathrm{ab}$ & $52.69 \pm 2.16 \mathrm{~b}$ & $258.35 \pm 10.51 \mathrm{a}$ & $0.550 \pm 0.006 \mathrm{~d}$ & $3.91 \pm 0.22 b c$ & $5.25 \pm 0.45 \mathrm{a}$ \\
\hline & Sarif & $0.06 \pm 0.00 \mathrm{~b}$ & $19.24 \pm 0.80 \mathrm{a}$ & $41.45 \pm 1.43 \mathrm{a}$ & $305.49 \pm 13.28 b$ & $0.557 \pm 0.009 \mathrm{~d}$ & $3.52 \pm 0.03 \mathrm{ab}$ & $5.47 \pm 0.23 \mathrm{a}$ \\
\hline & Sebou & $0.07 \pm 0.00 \mathrm{c}$ & $22.02 \pm 0.44 \mathrm{bc}$ & $53.75 \pm 1.16 \mathrm{~b}$ & $305.83 \pm 3.42 \mathrm{~b}$ & $0.510 \pm 0.006 \mathrm{c}$ & $3.77 \pm 0.05 \mathrm{~b}$ & $5.85 \pm 0.19 a$ \\
\hline \multirow{6}{*}{$40 \%$} & Boubter & $0.19 \pm 0.01 \mathrm{a}$ & $25.69 \pm 0.57 \mathrm{a}$ & $91.98 \pm 4.05 \mathrm{a}$ & $134.78 \pm 12.81 \mathrm{e}$ & $0.430 \pm 0.006 \mathrm{a}$ & $6.03 \pm 0.04 \mathrm{a}$ & $4.26 \pm 0.08 c$ \\
\hline & Lbyed & $0.26 \pm 0.01 \mathrm{~b}$ & $26.27 \pm 0.42 \mathrm{a}$ & $104.07 \pm 2.42 \mathrm{~b}$ & $99.65 \pm 2.50 \mathrm{~d}$ & $0.457 \pm 0.009 \mathrm{~b}$ & $.03 \mathrm{~b}$ & $.05 \mathrm{~b}$ \\
\hline & Lharcha & $0.50 \pm 0.00 \mathrm{f}$ & $27.21 \pm 0.35 \mathrm{a}$ & $109.04 \pm 1.46 \mathrm{~b}$ & $54.93 \pm 0.85 \mathrm{a}$ & $0.577 \pm 0.009 \mathrm{~d}$ & $8.26 \pm 0.03 \mathrm{f}$ & $3.30 \pm 0.04 \mathrm{a}$ \\
\hline & Maazouzia & $0.41 \pm 0.01 \mathrm{e}$ & $25.81 \pm 0.26 \mathrm{a}$ & $103.66 \pm 1.78 b$ & $63.00 \pm 1.41 \mathrm{ab}$ & $0.500 \pm 0.006 \mathrm{c}$ & $7.73 \pm 0.02 \mathrm{e}$ & $3.34 \pm 0.04 \mathrm{a}$ \\
\hline & Sarif & $0.32 \pm 0.01 \mathrm{c}$ & $26.41 \pm 0.90 \mathrm{a}$ & $93.47 \pm 0.90 \mathrm{a}$ & $81.75 \pm 1.13 \mathrm{c}$ & $0.513 \pm 0.009 \mathrm{c}$ & $6.89 \pm 0.02 c$ & $3.83 \pm 0.12 b$ \\
\hline & Sebou & $0.37 \pm 0.01 \mathrm{~d}$ & $27.15 \pm 0.21 \mathrm{a}$ & $105.27 \pm 0.65 b$ & $72.84 \pm 2.26 \mathrm{bc}$ & $0.500 \pm 0.006 \mathrm{c}$ & $7.15 \pm 0.03 \mathrm{~d}$ & $3.80 \pm 0.02 b$ \\
\hline \multirow{6}{*}{$60 \%$} & Boubter & $0.42 \pm 0.00 \mathrm{a}$ & $25.25 \pm 0.21 \mathrm{a}$ & $103.66 \pm 0.97 \mathrm{a}$ & $60.60 \pm 0.60 c$ & $0.633 \pm 0.009 \mathrm{a}$ & $9.08 \pm 0.03 \mathrm{a}$ & $2.78 \pm 0.03 b$ \\
\hline & Lbyed & $0.52 \pm 0.02 b$ & $26.23 \pm 0.42 \mathrm{a}$ & $109.01 \pm 2.15 \mathrm{a}$ & $50.98 \pm 2.63 b$ & $0.677 \pm 0.009 \mathrm{~b}$ & $9.86 \pm 0.03 b$ & $2.66 \pm 0.04 \mathrm{ab}$ \\
\hline & Lharcha & $0.67 \pm 0.02 \mathrm{~d}$ & $29.09 \pm 0.28 b$ & $139.05 \pm 1.27 \mathrm{~d}$ & $43.48 \pm 1.25 \mathrm{a}$ & $0.950 \pm 0.015 \mathrm{e}$ & $11.60 \pm 0.02 \mathrm{~d}$ & $2.51 \pm 0.02 \mathrm{a}$ \\
\hline & Maazouzia & $0.64 \pm 0.01 \mathrm{~d}$ & $28.65 \pm 0.72 b$ & $132.50 \pm 2.84 \mathrm{c}$ & $44.79 \pm 1.36 \mathrm{a}$ & $0.900 \pm 0.021 \mathrm{~d}$ & $10.64 \pm 0.30 \mathrm{c}$ & $2.70 \pm 0.10 b$ \\
\hline & Sarif & $0.54 \pm 0.02 \mathrm{c}$ & $26.24 \pm 0.27 \mathrm{a}$ & $116.35 \pm 1.15 b$ & $48.65 \pm 0.94 \mathrm{ab}$ & $0.690 \pm 0.006 \mathrm{~b}$ & $10.06 \pm 0.01 \mathrm{~b}$ & $2.61 \pm 0.03 \mathrm{ab}$ \\
\hline & Sebou & $0.58 \pm 0.02 \mathrm{c}$ & $27.90 \pm 0.54 \mathrm{~b}$ & $132.00 \pm 2.31 \mathrm{c}$ & $48.47 \pm 1.85 \mathrm{ab}$ & $0.813 \pm 0.012 \mathrm{c}$ & $10.16 \pm 0.03 b$ & $2.75 \pm 0.06 b$ \\
\hline \multirow{6}{*}{$100 \%$} & Boubter & $0.45 \pm 0.01 \mathrm{a}$ & $29.22 \pm 0.11 \mathrm{a}$ & $137.33 \pm 0.65 \mathrm{a}$ & $64.48 \pm 1.08 \mathrm{f}$ & $0.707 \pm 0.009 \mathrm{a}$ & $9.84 \pm 0.05 \mathrm{a}$ & $2.97 \pm 0.03 \mathrm{c}$ \\
\hline & Lbyed & $0.52 \pm 0.00 \mathrm{~b}$ & $29.74 \pm 0.52 a b$ & $139.59 \pm 2.28 \mathrm{a}$ & $56.82 \pm 0.66 \mathrm{e}$ & $0.780 \pm 0.010 \mathrm{~b}$ & $10.12 \pm 0.05 \mathrm{~b}$ & $2.94 \pm 0.05 \mathrm{c}$ \\
\hline & Lharcha & $0.77 \pm 0.01 \mathrm{f}$ & $31.36 \pm 0.08 \mathrm{~d}$ & $160.32 \pm 0.56 \mathrm{e}$ & $56.82 \pm 0.66 \mathrm{a}$ & $0.963 \pm 0.007 \mathrm{e}$ & $11.82 \pm 0.03 \mathrm{e}$ & $2.65 \pm 0.01 \mathrm{a}$ \\
\hline & Maazouzia & $0.69 \pm 0.00 \mathrm{e}$ & $30.02 \pm 0.20 \mathrm{ab}$ & $148.79 \pm 0.90 \mathrm{c}$ & $43.72 \pm 0.28 b$ & $0.900 \pm 0.021 \mathrm{~d}$ & $10.82 \pm 0.09 \mathrm{~d}$ & $2.78 \pm 0.02 b$ \\
\hline & Sarif & $0.58 \pm 0.01 \mathrm{c}$ & $30.20 \pm 0.38 \mathrm{bc}$ & $144.61 \pm 1.83 b$ & $52.07 \pm 0.51 \mathrm{~d}$ & $0.807 \pm 0.003 \mathrm{~b}$ & $10.22 \pm 0.03 b$ & $2.96 \pm 0.03 \mathrm{c}$ \\
\hline & Sebou & $0.65 \pm 0.01 \mathrm{~d}$ & $31.00 \pm 0.14 \mathrm{~cd}$ & $155.42 \pm 0.70 \mathrm{~d}$ & $47.97 \pm 0.86 \mathrm{c}$ & $0.853 \pm 0.007 \mathrm{c}$ & $10.42 \pm 0.04 \mathrm{c}$ & $2.98 \pm 0.02 \mathrm{c}$ \\
\hline
\end{tabular}

increased, shifting to slightly positive at the lowest ASW. The relationship between the $\mathrm{A} / \mathrm{T}$ ratio of the ear and $\mathrm{SPB}$ followed a similar pattern to that of $\mathrm{A} / \mathrm{g}_{\mathrm{s}}$ with shoot biomass, being negative regardless of the water regime. Moreover, the slope of the relationship decreased as the stress became more severe. However, the strongest relationship was attained at the lowest ASW $\left(\mathrm{r}^{2}=0.38,0.36,0.44,0.29\right.$ and 0.71 from $100 \%$ to $10 \%$ ASW, respectively). The $\mathrm{A} / \mathrm{T}$ of the leaf was, as for $\mathrm{A} / \mathrm{g}_{\mathrm{s}}$, more weakly correlated to shoot biomass than that of the ear, but in this case all the relationships were negative. As for the ear, the strongest correlation was attained at $10 \% \mathrm{ASW}\left(\mathrm{r}^{2}=0.07,0.24,0.31\right.$, 0.36 and 0.47 from $100 \%$ to $10 \%$ ASW, respectively).

The rates of photosynthesis on an area basis for the flag leaf were, in general, better correlated with GYP than those of the ear for each water regime: from 100 to $10 \% \mathrm{ASW}, \mathrm{r}^{2}=0.64$, $0.39,0.87,0.56$ and 0.62 for the flag leaf photosynthesis and $0.36,0.64,0.07,0.47$ and 0.52 for the ear photosynthesis. But the relationships between GYP and the whole-organ photosynthesis of either the ear or the flag leaf (Fig. 4) followed a similar pattern to those between SPB and the whole-organ photosynthesis (Fig. 2). In general, regardless of the ASW considered, the photosynthesis in the ear showed a higher correlation with grain yield than the photosynthesis in the flag leaf blade, and the fitting line within each ASW was different for the ear but not in the flag leaf. For both organs the strongest correlation (and the highest slope in the relationship) occurred at the highest level of stress (10\% ASW). For the flag leaf the correlation was not significant as ASW reached 60\% (Fig. 4b), whereas the relationship for the ear remained fairly steady as ASW increased (Fig. 4a).

The relationships between grain yield and the $\mathrm{A} / \mathrm{g}_{\mathrm{s}}$ ratio of both the ear and the flag leaf (Fig. 5) also followed a similar pattern to those between SPB and $\mathrm{A} / \mathrm{g}_{\mathrm{S}}$ (Fig. 3). The ear ratio correlated negatively with grain yield in all the water regimes (Fig. 5a). The relationship was strongest at full pot capacity, but remained relatively high at different levels of water stress. In addition, the slope of the relationship was much greater at full pot capacity, decreasing as the level of water stress increased. On the other hand, the $\mathrm{A} / \mathrm{g}_{\mathrm{S}}$ ratio of the ear correlated better with GYP (Fig. 5a) than the whole-ear photosynthesis (Fig. 4a). The 

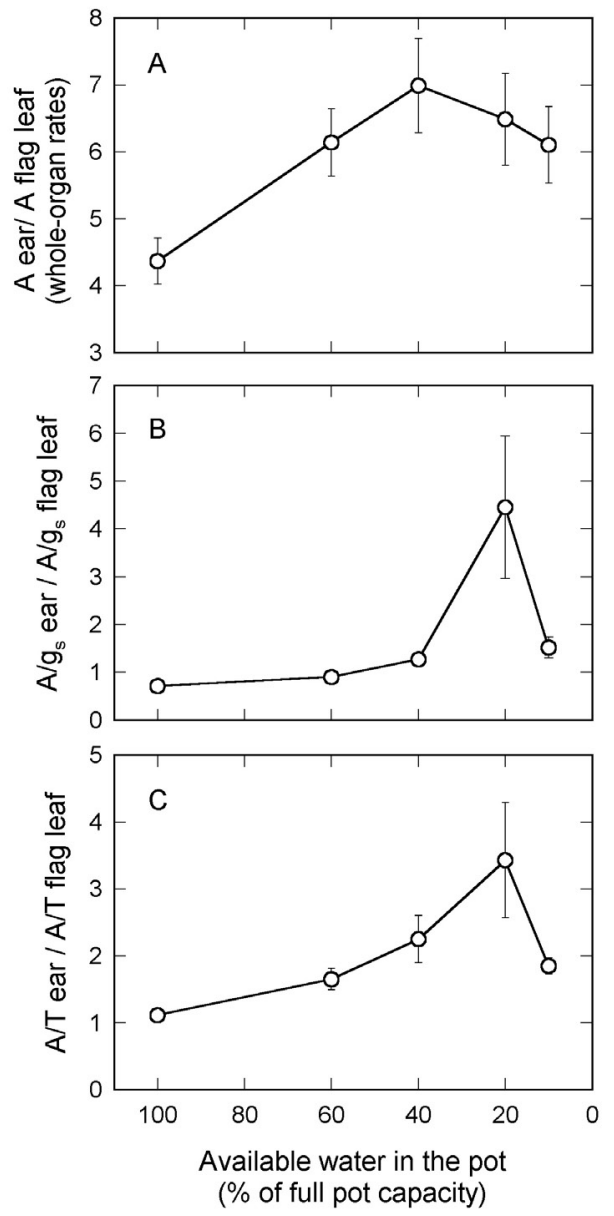

Figure 1. Evolution of the ear-to-leaf ratio for the whole-organ photosynthesis (a) and the ratios $\mathrm{A} / \mathrm{g}_{\mathrm{s}}$ (b) and $\mathrm{A} / \mathrm{T}$ (c) at different levels of available water in the pot substrate (ASW).

$\mathrm{A} / \mathrm{g}_{\mathrm{s}}$ ratio of the flag leaf showed a much weaker relationship with grain yield than that of the ear, independent of the water treatment considered (Fig. 5b). As for the ear, the relationship was also negative and highest at full pot capacity, decreasing its strength at lower ASW and shifting the slope to slightly positive at $20 \%$ and $10 \%$ ASW. The relationship between A/T for the ear and grain yield was also negative, regardless of the water regime considered, and weaker than that between $\mathrm{A} / \mathrm{g}_{\mathrm{s}}$ and grain yield $\left(\mathrm{r}^{2}\right.$ values were $0.44,0.08,0.85,0.57$ and 0.56 from $100 \%$ to $10 \%$ ASW, respectively). The relationship between the $\mathrm{A} / \mathrm{T}$ ratio of the flag leaf and grain yield was weaker than that of the ear $\mathrm{A} / \mathrm{T}$, independently of the water regime considered $\left(r^{2}\right.$ of $0.00,0.14,0.46,0.41$ and 0.46 from $100 \%$ to $10 \%$ ASW, respectively), but this time the slope remained negative in all cases.

\section{DISCUSSION}

The values of relative water content at full pot capacity are comparable with these reported for well-watered wheat growing either in the field or in pots. The relative water content values of $40 \%$ attained at $10 \%$ available soil water (ASW)



Figure 2. Correlations between the total net photosynthesis of the ear (upper) and the flag leaf blade (lower) with the total above-ground plant biomass at anthesis for plants growing at different levels of available water in the substrate (ASW). Each point represents a single measurement (either of gas exchange or biomass) of a plant, with 3 plants measured for each of the 6 genotypes used. ns, not significant; $*, * *, * * *$ : significant at the $0.05,0.01,0.001$ probability level, respectively.

corresponded to a very severe water stress. The values of gas exchange traits $\left(\mathrm{A}, \mathrm{g}_{\mathrm{s}}\right.$ and $\left.\mathrm{T}\right)$ per unit leaf area of flag leaves at full pot capacity were also in the same range as those reported as typical for fully irrigated bread [1] and durum wheat [2, but only $g_{s}$ was reported], whereas the ear values were in general higher than those previously published in durum wheat [2] and in different cereals [5, but on detached organs]. An underestimation of the total photosynthetic area (and thus an overestimation of gas exchange rates) of the ear should not be disregarded in this study. However, whereas in the previous study on intact plants [2] gas exchange of the ear was measured during grain filling, in the present study measurements were done at anthesis, thus avoiding the high respiration rates associated with grain filling [17], which strongly diminishes the net photosynthesis rates of the ear [2]. Nevertheless, the $\mathrm{C}_{\mathrm{i}}$ / $\mathrm{C}_{\mathrm{a}}$ ratio was consistently higher in the ear than in the flag leaf, not only in well-watered conditions but also at all the levels of water stress assayed, suggesting a higher internal (i.e. respiratory) source of $\mathrm{CO}_{2}$ in the ears than in the leaf (or a lower intrinsic photosynthetic capacity).

Both organs showed the same pattern of changes in $C_{i} / C_{a}$ as ASW decreased. A decrease in the $C_{i} / C_{a}$ ratio is a normal 


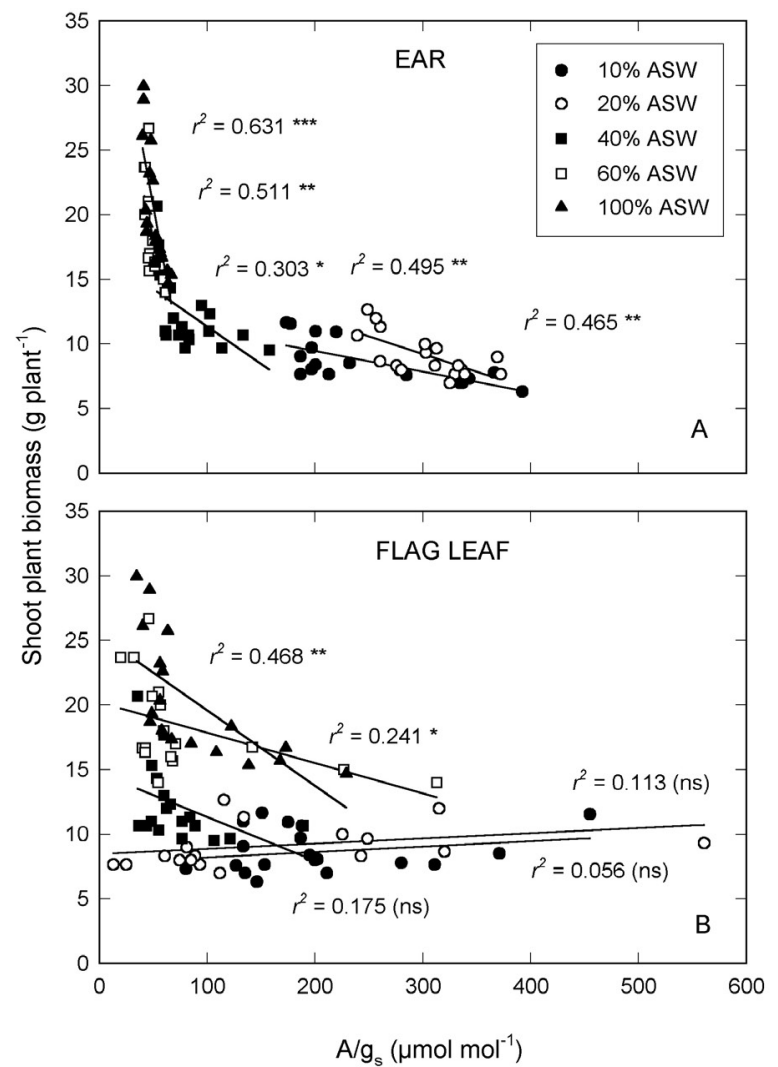

Figure 3. Correlations between the ratio of net photosynthesis to stomatal conductance of the ear (upper) and the flag leaf blade (lower) with the total above-ground plant biomass at anthesis for plants growing at different levels of available water in the substrate (ASW). Each point represents a single measurement (either of gas exchange or biomass) of a plant, with 3 plants measured for each of the 6 genotypes used. ns, not significant; *,**,***: significant at the $0.05,0.01,0.001$ probability level, respectively.

response to mild and moderate water stress (60\% and $40 \%$ ASW), suggesting stomatal limitation of photosynthesis, whereas at severe water stress $(20 \%$ and $10 \%$ ASW) the ratio increased in accordance with a non-stomatal limitation of photosynthesis $[13,16,30]$.

\subsection{Comparative photosynthetic performance of the two organs}

In response to water stress, the photosynthesis in the ear was less affected than the flag leaf, irrespective of how the rates are expressed: on a leaf area basis or per whole organ. Similarly, it has been reported that the ear shows a better performance than the leaves in response to water stress [6]. Morgan [19] found that spikelets maintain a higher water potential than leaves under water stress, while spikelets have also been demonstrated to be more effective than leaves in osmotic adjustment [20, 27].

At full pot capacity, TE (the ratio A/T) tended to be slightly higher in the ear than the flag leaf, whereas the $\mathrm{A} / \mathrm{g}_{\mathrm{s}}$ ratio was more than $40 \%$ lower in the ear. For tetraploid wheats, gas exchange measurements on detached organs also showed a

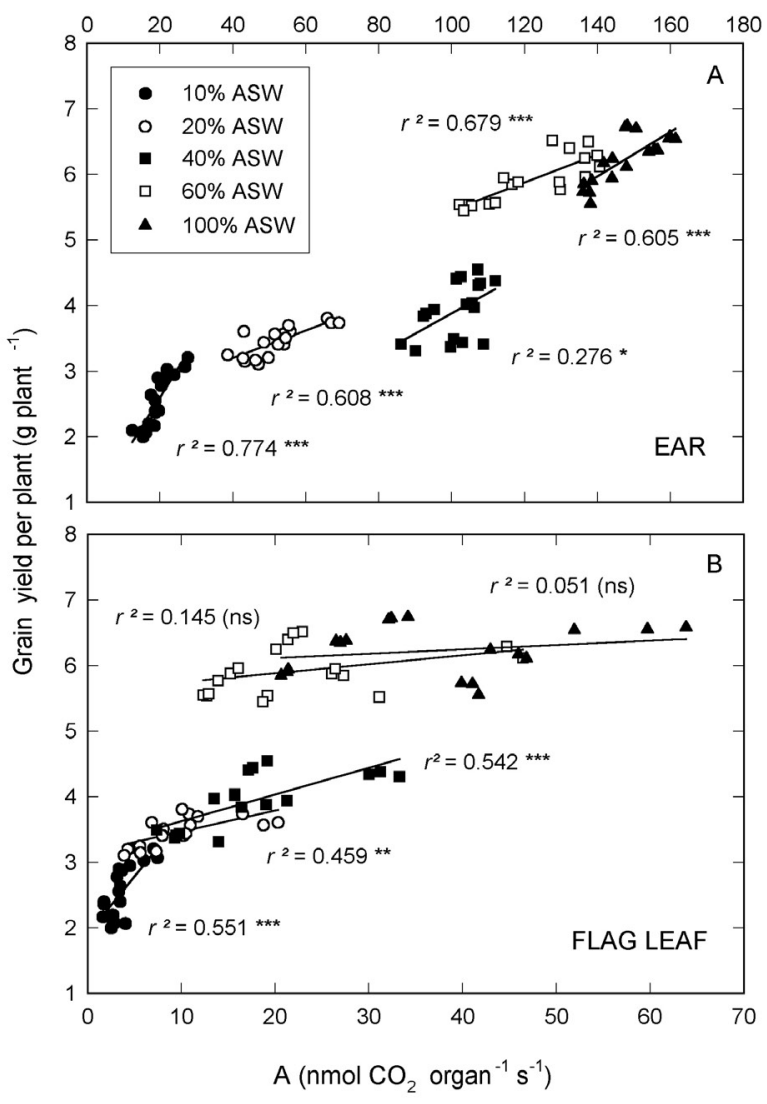

Figure 4. Correlations between the total net photosynthesis of the ear (upper) and the flag leaf blade (lower) measured at anthesis with the grain yield of plants growing at different levels of available water in the substrate (ASW). Each point represents a single measurement (either of gas exchange or grain yield) of a plant, with 3 plants measured for each of the 6 genotypes used. ns, not significant; $*, * *, * * *$ : significant at the $0.05,0.01,0.001$ probability level, respectively.

somewhat higher $\mathrm{A} / \mathrm{T}$ ratio in the ear than the flag leaf, whereas no differences were found for bread wheat [5]. Reports on carbon isotope discrimination values from photoassimilates also support a higher transpiration efficiency in the ear than the flag leaf of durum wheat under well-watered conditions $[2,7,8]$. The lower $\mathrm{A} / \mathrm{g}_{\mathrm{s}}$ ratio in the ear than the flag leaf could be due to a higher internal (i.e. respiratory) source of $\mathrm{CO}_{2}$. In fact, the photosynthetic rate as well as the $\mathrm{A} /$ $\mathrm{g}_{\mathrm{S}}$ and $\mathrm{A} / \mathrm{T}$ ratios in the ear are normally underestimated during gas exchange measurements because the high rates of dark respiration usually accounted for by the growing kernels are not considered [2]. The ear bracts probably refix this respiratory $\mathrm{CO}_{2}$, therefore improving even more the transpiration efficiency of the ear [8]. Moreover, in response to water stress, the higher stability in the A rates of the ear led to a greater increase in the $\mathrm{A} / \mathrm{g}_{\mathrm{S}}$ and $\mathrm{A} / \mathrm{T}$ ratios in the ear than the flag leaf.

\subsection{Role of both organs in yield}

These results indicate that the photosynthetic contribution of the ear during grain filling is clearly greater than that of the flag leaf, not only under water stress, as reported before for 




Figure 5. Correlations between the ratio of net photosynthesis to stomatal conductance of the ear (upper) and the flag leaf blade (lower) with the grain yield of plants growing at different levels of available soil water in the substrate (ASW). Each point represents a single measurement (either of gas exchange or grain yield) of a plant, with 3 plants measured for each of the 6 genotypes used. ns, not significant; ***,***: significant at the $0.05,0.01,0.001$ probability level, respectively.

bread wheat and barley [15], but also under favourable water conditions. This is consistent with the results in durum wheat under well-watered conditions reported by Araus et al. [2] and derived from shading experiments as well as from comparing the stable carbon composition of grains with those of the photoassimilates from both organs. Early experiments for bread wheat under unlimited water conditions using ${ }^{14} \mathrm{C}$ labelling indicated that, at mid-grain filling, the ear contributed more assimilates than the flag leaf to growing kernels [23].

However, as the level of stress increases, the improvement of the relationship of flag leaf photosynthesis with SBP and grain yield (although the photosynthesis of the ear still correlated better with shoot biomass and grain yield) suggests the relative contribution from the flag leaf photosynthesis increases, which is consistent with the hypothesis of a shift from sink to source limitation of grain yield [25, 28]. Other factors may act against a higher relative contribution of the flag leaf as water stress develops. The senescence of the flag leaf in response to water stress is usually faster than that of the ear (which is a common observation in Mediterranean rainfed environments). Moreover, the relative contribution of ear photosynthates to grain filling can increase under water stress, because water shortage reduces photosynthesis and transfer of assimilates to the grains less for ears than for flag leaves [11].

\subsection{Some implications for breeding}

These results suggest that breeding strategies to increase whole-flag leaf photosynthesis (mostly through an increase in blade area) are less effective in improving yield than increasing whole-ear photosynthesis, whatever water regime is targeted. Nevertheless, the best genotype (Lharcha) in terms of biomass in all the range of water was that combining the highest rates of both ear and flag leaf photosynthesis (either on a whole-area basis or per unit area). Moreover, Lharcha was the best in terms of yield from moderate to severe water stress. It is interesting to highlight that this is a traditional variety. The results also show that genotype variability exists for both ear and flag leaf photosynthesis (as well as for the other gas-exchange-derived traits) either in well-watered or water-stressed conditions.

Total photosynthesis of the ear was markedly higher than that of the flag leaf, probably due to the comparatively larger green surface of the former [5 and references herein]. Blum [5] has already reported for tetraploid (cultivated plus wild) wheat a green surface area almost four times greater in the ear than the flag leaf. The contribution of awns to the total photosynthetic area of ears may be important. Thus differences in whole-ear area, as a consequence of differences in the total area of awns, accounts for the greater ear photosynthesis in barley than in bread wheat [15] and in tetraploid wheat than in hexaploid wheat [21]. Nevertheless, in Blum [5] net photosynthesis rates per unit area in the ear of the tetraploid wheat were only $25 \%$ of those of flag leaves. As a consequence, total ear photosynthesis only reached $90 \%$ of that of the flag leaf [5], which is clearly lower than in the present study.

Under well-watered conditions the range of differences in ear photosynthesis across the six genotypes studied was only slightly larger when rates were expressed per whole organ instead of on an area basis, but increased as the water stress increased. However, Blum [5] reported differences in wholeear net photosynthesis and transpiration between varieties and between species of bread wheat, durum wheat and barley, associated largely with differences in surface area rather than rates per unit area.

Photosynthesis is generally more limiting to yield under stress than under optimal conditions, as indicated by the higher association commonly observed between yield and aboveground biomass at maturity. While selection for higher rates (usually on a leaf area basis) of leaf photosynthesis has not generally improved yield under temperate conditions [10; but see recent results in 14], most probably because the source is less limiting than the sink, greater success might be expected for higher rates under water stress.

It may be argued that the better correlation of the photosynthesis of the whole ear with shoot biomass and grain yield compared with that of the whole flag leaf blade merely reflects the differences in sink size (i.e. total number of florets per ear which is associated with the size of the ear). However, TE and $\mathrm{A} / \mathrm{g}_{\mathrm{s}}$, which are independent of the organ size, were again much better correlated with shoot biomass and grain yield in the ear than in the flag leaf. These results again emphasise that the ear is the main photosynthetic organ contributing to grain filling in 
durum wheat, and agree with the conclusion of a previous study in which the photosynthesis of the flag leaf was prevented [2].

It has been postulated that under limited water conditions, any improvement in transpiration efficiency (TE, the $\mathrm{A} / \mathrm{T}$ ratio) should result in higher biomass if the total water used (i.e. by transpiration) is similar [26]. However, in our results most of the correlations across genotypes (within a given water regime) between either the $\mathrm{A} / \mathrm{T}$ or $\mathrm{A} / \mathrm{g}_{\mathrm{s}}$ ratio against shoot biomass or grain yield were negative, suggesting that those varieties showing a higher ratio were those more stressed and used less water. Moreover, for wheat in Mediterranean conditions lower water availability during growth frequently decreases water-use efficiency (WUE, the ratio of dry matter accumulated with total water evapotranspired over the same period), mostly because of the increase in the evaporative loss due to a decrease in canopy coverage of the soil $[22,32]$. But, as for TE and $\mathrm{A} / \mathrm{g}_{\mathrm{s}}$, the relationship of WUE with grain yield within a given water status was negative (data not shown), suggesting those genotypes with the highest WUE were the least productive, probably because they were more stressed (and thus had a lower stomatal conductance), therefore transpiring less water but at the same time achieving lower rates of photosynthesis.

Acknowledgements: This study was supported in part by the research project AGL2002-04285-C03 from the Spanish Ministry of Science and Technology. We acknowledge the support of Drs. A. Laamarti, M. Benlaghlid and M. El Mekkaoui from the ENAM, Meknes, Dr. P. Rovira from the UB, Barcelona and Mrs. L. Qariani from the University Moulay Ismail Meknes. We convey our deep sorrow and hearfelt condolences to the family of Hanane Abbad.

\section{REFERENCES}

[1] Araus J.L., Tapia L., Photosynthetic gas exchange characteristics of wheat flag leaf blades and sheaths during grain filling. The case of a spring crop grown under Mediterranean climate conditions, Plant Physiol. 85 (1987) 667-673.

[2] Araus J.L., Brown H.R., Febrero A., Bort J., Serret M.D., Ear photosynthesis, carbon isotope discrimination and the contribution of respiratory $\mathrm{CO}_{2}$ to differences in grain mass in durum wheat, Plant Cell Environ. 16 (1993) 383-392.

[3] Baldy C., Effet du climat sur la croissance et le stress hydrique des blès en méditerranée occidentale, in: Ben Salem M., Monneveux P. (Eds.), tolérance à la sécheresse des céréales en zone méditerranéenne, Les Colloques INRA 64, Paris, 1993, pp. 83-100.

[4] Biscoe P.V., Gallagher J.N., Littleton E.J., Monteith J.L., Scott R.K., Barley and its environment. IV. Sources of assimilate for the grain, J. Appl. Ecol. 12 (1975) 295-318.

[5] Blum A., Photosynthesis and transpiration in leaves and ears of wheat and barley varieties, J. Exp. Bot. 36 (1985) 432-440.

[6] Blum A., Mayer J., Gozlan G., Associations between plant production and some physiological components of drought resistance in wheat, Plant Cell Environ. 6 (1983) 219-225.

[7] Bort J., Febrero A., Amaro T., Araus J.L., Role of awns on ear water use efficiency and grain weight in barley, Agronomie 2 (1994) 133-139

[8] Bort J., Brown H.R., Araus J.L., Refixation of respiratory $\mathrm{CO}_{2}$ in the ears of $C_{3}$ cereals, J. Exp. Bot. 47 (1996) 1567-1575.

[9] Duffus C.M., Nutbeam A.R., Scragg P.A., Photosynthesis in the immature cereal pericarp in relation to grain growth, in: Jeffcoat B., Hawkins A.F., Stead A.D. (Eds.), regulation of sources and sinks in crop plants, Monograph No. 12, British Plant Growth Regulator Group, Long Ashton, Kent, 1985, pp. 243-256.

[10] Evans L.T., Processes, genes and yield potential, in: Buxton D.R., Shibles R., Forsberg R.A., Blad B.L., Asay K.H., Paulsen G.M., Wilson R.F. (Eds.), International Crop Science I. Crop Science Society of America, Inc., Madison, 1993, pp. 687-696.
[11] Evans L.T., Bingham J., Jackson P., Sutherland J., Effect of awns and drought on the supply of photosynthate and its distribution within wheat ears, Ann. Appl. Biol. 70 (1972) 67-76.

[12] Evans L.T., Wardlaw I.F., Fischer R.A., Wheat, in: Evans L.T (Ed.), crop physiology; some case histories, Cambridge University Press, Cambridge, 1975, pp. 101-150.

[13] Grieu P., Guehl J.M., Aussenac G., The effect of soil and atmospheric drought on photosynthesis and stomatal control of gas exchange in three coniferous species, Physiol. Plant. 73 (1988) 97104.

[14] Gutiérrez-Rodríguez M., Reynolds M.P., Larqué-Saavedra A., Photosynthesis of wheat in a warm, irrigated environment. II: Traits associated with genetic gains in yield, Field Crop Res. 66 (2000) 51-62.

[15] Johnson R.R., Frey N.M., Moss D.N., Effect of water stress on photosynthesis and transpiration of flag leaves and spikes of barley and wheat, Crop Sci. 14 (1974) 728-731.

[16] Jones H.G., Partitioning stomatal and non stomatal limitations to photosynthesis, Plant Cell Environ. 8 (1985) 95-104.

[17] Knoppik D., Selinger H., Ziegler-Jöns A., Differences between the flag leaf and the ear of a spring wheat cultivar (Triticum aestivum cv. Arkas) with respect to the $\mathrm{CO}_{2}$ response of assimilation, respiration and stomatal conductance, Physiol. Plant. 68 (1986) 451-457.

[18] Loss S.P., Siddique K.H.M., Morphological and physiological traits associated with wheat yield increases in Mediterranean environments, Adv. Agron. 52 (1994) 229-276.

[19] Morgan J.M., Changes in diffusive conductance and water potential of wheat plants before and after anthesis, Aust. J. Plant Physiol. 4 (1977) 75-86.

[20] Morgan J.M., Osmotic adjustment in the spikelet and leaves of wheat, J. Exp. Bot. 31 (1980) 655-665.

[21] Olugbemi L.B., Bingham J., Austin R.B., Ear and flag leaf photosynthesis of awned and awnless Triticum species, Ann. Appl. Biol. 84 (1976) 231-240.

[22] Oweis T., Zhang H., Pala M., Water use efficiency of rainfed and irrigated bread wheat in a Mediterranean environment, Agron. J. 92 (2000) 231-238.

[23] Rawson H.M., Evans L.T., The pattern of grain growth within the ear of wheat, Aust. J. Biol. Sci. 23 (1970) 753-764.

[24] Sinclair T.R., Ludlow M.M., Influence of water supply on the plant water balance of four tropical grain legumes, Aust. J. Plant Physiol. 13 (1986) 329-341.

[25] Slafer G.A., Satorre E.H., Andrade F.H., Increases in grain yield in bread wheat from breeding and associated physiological changes, in: Slafer G.A. (Ed.), genetic improvement of field crops, Marcel Dekker Inc., New York, 1994, pp. 1-68.

[26] Turner N.C., Water use efficiency of crop plants: potential for improvement, in: Buxton D.R., Shibles R., Forsberg R.A., Blad B.L., Asay K.H., Paulsen G.M., Wilson R.F. (Eds.), International Crop Science I. Crop Science Society of America, Inc., Madison, 1993, pp. 75-82.

[27] $\mathrm{Xu} \mathrm{H.-L.,} \mathrm{Ishii} \mathrm{R.,} \mathrm{Effects} \mathrm{of} \mathrm{water} \mathrm{deficit} \mathrm{on} \mathrm{photosynthesis} \mathrm{in}$ wheat plants, Jap. J. Crop Sci. 59 (1990) 384-389.

[28] Voltas J., Romagosa I., Lafarga A., Armesto A.P., Sombrero A., Araus J.L., Genotype by environment interaction for grain yield in two-rowed barley grown under semiarid conditions, Eur. J. Agron. 9 (1999) 147-155.

[29] von Caemmerer S., Farquhar G.D., Some relationships between the biochemistry of photosynthesis and the gas exchange of leaves, Planta 153 (1981) 376-387.

[30] Wise R.R., Frederick J.R., Alm D.M., Kramer D.M., Hesketh J.D., Crofts A.R., Ort D.R., Investigation of the limitations to photosynthesis induced by leaf water deficit in field-grown sunflower ( Helianthus annuus L.), Plant Cell Environ. 15 (1990) 755-756.

[31] Zadoks J.C., Chang T.T., Konzak C.F., A decimal code for the growth stage of cereals, Euphyt. Bull. 7 (1974) 42-52.

[32] Zhang H., Oweis T.Y., Garabet S., Pala M., Water-use efficiency and transpiration efficiency of wheat under rain-fed conditions and supplemental irrigation in a Mediterranean-type environment, Plant and Soil 201 (1998) 295-305. 